\title{
METALS IN SOIL AND AMERICAN CHESTNUT TISSUE IN EXPERIMENTAL SOIL TREATMENTS PLOTS ON A COAL MINE RECLAIMED SITE ${ }^{1}$
}

\begin{abstract}
J.M. Bauman ${ }^{2}$, R. Brisbin, K. Gilland, and E.T. Cline
Abstract: The Appalachian Regional Reforestation Initiative outlines planting methods that include preparation of a deep-rooting zone for healthy tree establishment (> $1.3 \mathrm{~m}$ deep). Continued monitoring may show that soil-ripping has pronounced effects in later years. However, little is known about the interactions of reclamation methods, buried metals, and micronutrients in soils on reclaimed coal mined sites. This study examined soil samples and plant tissue in eight-year-old pure American (Castanea dentata) and hybrid chestnuts $\mathrm{BC}_{1} \mathrm{~F}_{3}$, and $\mathrm{BC}_{2} \mathrm{~F}_{3}(C$. dentata $\times C$. mollissima $)$ on a reclaimed coal mine site located in Dresden, Ohio under various treatments: 1 ) untreated control plots, 2) plots plowed and disked to $30 \mathrm{~cm}$ depth, 3) plots deep-ripped to $1 \mathrm{~m}$ depth, and 4) a combination of ripped and plowed/disked. Soil samples were collected in triplicate from all four treatments $(n=3)$. Leaves were collected from a randomly selected subset of 108 trees $(n=9)$. Flowers were collected from this subset (22 individuals), representing all treatments. Soil, leaves, and floral tissue were analyzed for silver (Ag), aluminum (Al), arsenic (As), cadmium $(\mathrm{Cd})$, copper $(\mathrm{Cu})$, manganese $(\mathrm{Mn})$, lead $(\mathrm{Pb})$, selenium $(\mathrm{Se})$, and zinc $(\mathrm{Zn})$ using inductively coupled plasma-mass spectrometry. No differences were detected when metal concentrations in soil, foliage, and floral tissue were compared among soil preparation treatments and chestnut tree types. Soil concentrations of $\mathrm{Cu}, \mathrm{Mn}$, and Se were detected at higher levels than county averages. Differences were noted when metal concentrations in soil were compared to chestnut leaves and chestnut floral tissue $(P<0.05)$. Elements including As and $\mathrm{Cd}$ were detected in soils but not found in tree tissue, indicating no potential transfer into the food chain. However, Se and $\mathrm{Cu}$ concentrations in chestnut floral tissue were significantly higher when compared to foliage $(P=0.004$ and $<0.0001)$, which merits monitoring focused on metal concentrations in developing chestnut seeds.
\end{abstract}

${ }^{1}$ Poster presented at the 2016 National Meeting of the American Society of Mining and Reclamation, Spokane, WA Reclaiming the West June 4-9, 2016. Published by ASMR; 1305 Weathervane Dr., Champaign, IL 61821.

2 Jenise M. Bauman, Professor, Huxley College of the Environment, Western Washington University, Poulsbo, WA, 98370; Ryan Brisbin, Student, University of Washington, Tacoma, WA, 98402; Keith Gilland, Professor, University of Wisconsin-Stout, Menomonie, WI 54751; and Erica T. Cline, Professor, University of Washington, Tacoma, WA, 98402

Journal American Society of Mining and Reclamation, 2016 Volume 5, Issue 2 pp 1-18 DOI: http://doi.org/10.21000/JASMR16020001 


\section{$\underline{\text { Introduction }}$}

Surface mining for coal has caused significant disturbance and fragmentation to Appalachian forestlands in the eastern United States. These large-scale soil disturbances have removed nearly one million hectares of native deciduous forests in eastern North America (USGS 2011), resulting in long-term changes in soil chemistry, water and nutrient cycles, and topographical transformations (Saylor 2008; Wickham et al., 2007). Growing environmental concern led to federal mandates under the Surface Mining Control and Reclamation Act (SMCRA) of 1977 which enforced the placement of topsoil over mine spoil (45 cm depth), graded contours, and the establishment of a productive vegetation cover. Reclamation achievements following this act were evident, resulting in short-term improvements in land stability, water quality, and human safety (Boyce 1999). However, some reclamation lands degrade to unproductive landscapes comprised of non-native species whose aggressive growth rates deter the establishment of native plants and keep forests fragmented with non-native grasslands (Cavender et al., 2014; Bauman et al., 2015). Therefore, native tree regeneration is delayed and landscapes remain in a state of arrested succession (Holl 2002).

The Appalachian Regional Reforestation Initiative (ARRI) has outlined the Forestry Reclamation Approach (FRA) which recommends planting methods that encourage healthy tree establishment. The premise of the ARRI reclamation is that established trees can add organic matter to the soil, attract seed-carrying wildlife, and harbor beneficial microbial symbionts that may aid in the establishment of other tree species leading to forest recovery (Zipper et al., 2011). A hardwood species with the potential to be a valuable restoration tree for use in the Appalachian region (Jacobs et al., 2013) is the American chestnut (Castanea dentata Marsh. Borkh.). Backcrossed breeding strategies initiated by the U.S. Forest Service and The American Chestnut Foundation (TACF) have produced potentially blight resistant genetic lines (designated here as "tree types"). Research to develop strategies for chestnut re-introduction into the Appalachian landscape is ongoing (Bauman et al., 2012; Clark et al., 2012; Gilland and McCarthy, 2012; Skousen et al., 2013). Using chestnut coupled with soil preparation methods such as deep soilripping results in high seedling survival and vigorous growth rates, at least in the short term (McCarthy et al., 2008; Bauman et al., 2014). 
Long-term monitoring may show that deep soil-ripping has pronounced effects in later years on chestnut survival, tree growth, and soil development. Benefits may include greater access to water, nutrients, and beneficial microbial symbionts. However, little is known about the development of reclamation mine soils with regard to buried mine spoil and metal uptake. Topsoil salvage is recommended for reclamation (Skousen et al., 2011), however fragmented geologic materials (mine spoil) may also be incorporated (Daniels and Amos, 1985). It may be that the 1 $\mathrm{m}$ soil-ripping method may inadvertently mix buried spoils where buried rock and spoil are approximately $45 \mathrm{~cm}$ below the surface. In addition, established plants can influence changes in chemistry and moisture levels by pulling water from deeper soils by hydraulic lift (Richards and Caldwell, 1987; Bai et al., 2009). As deep-soil ripping on reclamation sites encourage root growth, root exploration for water could result in the translocation of metals from the deeper mine spoil into the vicinity of the root zone, causing clean soils to become mixed with metals associated with buried spoil. Metal contaminations in soils exceeding normal background levels can result in heavy metals transferred into plant tissue that interacts with the food chain (Chen et al., 2012).

The objective of this current study was to compare metal accumulation in soil and plant tissue in eight-year-old chestnut trees. Soil and tissue were analyzed for $\mathrm{Ag}, \mathrm{Al}, \mathrm{As}, \mathrm{Cd}, \mathrm{Cu}, \mathrm{Mn}, \mathrm{Pb}$, $\mathrm{Se}$, and $\mathrm{Zn}$. We hypothesized differences in metal accumulation in soil and tree tissue due to site preparation treatments after eight growing seasons on reclaimed SMCRA grassland. Treatments consisted of controls, plots that were plowed and disked to a $30 \mathrm{~cm}$ depth, plots that were soilripped to $1 \mathrm{~m}$, and a combination of ripped + plowed and disked. In addition, metal accumulations in tree types were assessed. Reclamation trees consisted of pure American $(C$. dentata $), \mathrm{BC}_{1} \mathrm{~F}_{3}$ chestnut (75\% American chestnut, $25 \%$ Chinese chestnut), and $\mathrm{BC}_{2} \mathrm{~F}_{3}$ chestnut ( $\sim 88 \%$ American chestnut and $\sim 12 \%$ Chinese chestnut). In addition to foliage, floral tissue was also collected at this time to detect allocation of metals to reproductive tissue, which may be indicative of potential mineral and metal transfer to reproductive tissue.

\section{$\underline{\text { Methods }}$}

\section{$\underline{\text { Study Site }}$}

This study is part of an ongoing field project on a coal mine site reclaimed under SMCRA in 1978. Treatments using FRA soil-ripping recommendations were initiated in the spring of 2007 and described in detail in Bauman et al. (2014). The field site used for this study is located in the 
Tri-Valley Wildlife Management Area (TVWMA), Muskingum County, Ohio, (40 6' 44" N, -81 58 ' 23" W). Three blocks were designated $(117 \mathrm{~m} \times 40 \mathrm{~m})$ with four $18 \times 36 \mathrm{~m}$ treatment plots contained within. In each block, the following treatments were established: 1) $\mathrm{C}=$ control plots that were left undisturbed, 2) $\mathrm{PD}=$ plots that were plowed and disked to a $30 \mathrm{~cm}$ depth, 3) $\mathrm{R}=$ plots that were cross- ripped to a depth of $1 \mathrm{~m}$, and 4) RPD = plots that were ripped to $1 \mathrm{~m}$ depth and plowed and disked. The deep soil-ripping treatments were installed using a D-6 dozer with a single-blade $1 \mathrm{~m}$ steel ripper bar attachment. The bulldozer cross-ripped the soil by one pass across the plots and one pass perpendicular to create a cross-ripped $2.5 \mathrm{~m} \times 2.5 \mathrm{~m}$ on center grid to a $1 \mathrm{~m}$ depth. The plowed and disked plot was installed using a 250 horse power conventional tractor with chisel plow and disk attachment. Two passes were made to disturb vegetation and till soil to a depth of approximately $30 \mathrm{~cm}$. For the combination ripped and plow/disked plots, soils were first cross-ripped followed by two passes of the plow and disk pulled by conventional tractor.

\section{$\underline{\text { Soil and Tissue Metal Analysis }}$}

In June of 2015, soil sampling locations were randomly selected across treatments and soil samples were collected at the base of seedlings to assess differences in the accumulation of metals and arsenic in soils that were deep-ripped (R and RPD) compared to those soils that were disturbed to a lesser depth $(30 \mathrm{~cm}$ in PD) or not disturbed (C). Soil was collected using a soil probe $(2.5 \mathrm{~cm}$ in diameter) at a depth of $18 \mathrm{~cm}$. Soil samples were collected in triplicate from all four treatments $(n=3)$. Due to total chestnut mortality in two of the three control plots, soil was collected from the upper, middle, and lower sectors of the control plots. Leaves were collected from 108 trees randomly selected across treatments $(\mathrm{n}=9)$ by removing a $30 \mathrm{~cm}$ segment of a top branch, which represented new growth. Of these, 22 individuals, representing all treatment types, were flowering and those flowers were collected at this time. Due to control plot mortality, tissue could not be sampled from two of the three control plots resulting in non-replicated control plots.

\section{Sample Digestion and Elemental Analysis}

In the laboratory, plant tissue was washed, and both tissue and soil were oven-dried, and homogenized using a mortar and pestle. Approximately 0.1 grams of the dried samples were digested in concentrated nitric acid at $170^{\circ} \mathrm{C}$ in Teflon ${ }^{\circledR}$ lined vessels in a CEM Mars 5 microwave digester and then diluted five times with water. Samples were analyzed for $\mathrm{Ag}, \mathrm{Al}, \mathrm{As}, \mathrm{Cd}, \mathrm{Cu}$, $\mathrm{Mn}, \mathrm{Pb}$, and $\mathrm{Zn}$ using inductively coupled plasma-mass spectrometry (ICP-MS) at the Community Innovation Zone Laboratory at the University of Washington, Tacoma, WA. 


\section{$\underline{\text { Statistical Analysis }}$}

Differences in soil metal concentrations across treatments (Control, Ripped, Plowed and disked, Ripped and plowed and disked) were analyzed using one-way analysis of variance (ANOVA; Sokal and Rohlf, 1995). Differences in soil and foliage metal concentrations were analyzed using two-way Analysis of Variance where Treatment and Tree type (Pure American, $\mathrm{BC}_{1} \mathrm{~F}_{3}, \mathrm{BC}_{2} \mathrm{~F}_{3}$ ) were examined as main effects along with their interaction (Treatment*Tree type) using Type II ANOVA (Fox and Weisberg, 2011). All residuals were examined for the assumption of normality using quantile-quantile plots and histograms. Levene's test implementing the "car" package (Wuertz, 2010) was used to test for homogeneity of variance. All analyses were conducted using the R statistical programing environment (R Development Core Team 2013). Mean metal concentrations in soil and chestnut tissue are reported with $95 \%$ confidence intervals and compared to Ohio mean background levels collected from 36 Ohio counties, including Muskingum (Cox and Colvin, 1996; Logan and Miller, 1983). Due to unequal variances, a paired t-test was used to analyze differences in metal concentrations between soils and foliage and for foliage and floral tissue. When required, a log data transformation was used to meet the assumption of a normal distribution.

\section{$\underline{\text { Results }}$}

When all soil metals were compared using a MANOVA by treatment and tree type, no statistically significant differences existed $\left(F_{(3,27)}=1.01, P=0.46\right.$ and $F_{(2,27)}=1.11, P=0.35$, respectively). Additionally, when all foliar metals were compared by treatment and tree type, no differences or interactions existed $(P>0.05$; Table 1). Lastly, no differences existed when leaf tissue was compared to floral tissue by treatment, tree type, and the interaction $(P>0.05$; Table 2$)$. Therefore, data for metal concentrations were pooled among soil and tissue type and presented in Tables 3 and 4. 
Table 1. Two-way Analysis of Variance results for leaf metal concentrations by soil treatment and tree type at Tri-Valley Wildlife Management Area. Response variables were Treatment (TMT; control, plowed and disked, ripped, and ripped and plowed/disked) and Tree type (Pure American, $\mathrm{BC}_{1} \mathrm{~F}_{3}$, and $\mathrm{BC}_{2} \mathrm{~F}_{3}$ ). Superscripts indicate required data transformations to achieve residual normality.

\begin{tabular}{lllll}
\hline Metal & & $F$ & $\mathrm{df}$ & $P$ \\
\hline $\mathrm{Ag}^{1}$ & TMT & 0.1666 & 3 & 0.7572 \\
& Tree type & 0.3119 & 2 & 0.3354 \\
& TMT:Tree type & 1.0307 & 6 & 0.3049 \\
$\mathrm{Al}^{2}$ & TMT & 0.8629 & 3 & 0.4641 \\
& Tree type & 0.1842 & 2 & 0.8321 \\
& TMT:Tree type & 1.2018 & 6 & 0.3145 \\
$\mathrm{As}^{*}$ & - & - & - & - \\
$\mathrm{Cd}^{*}$ & - & - & - & - \\
$\mathrm{Cu}^{* *}$ & - & - & - & - \\
$\mathrm{Mn}^{*} 5$ & TMT & 0.5913 & 3 & 0.6226 \\
& Tree type & 0.8586 & 2 & 0.4278 \\
$\mathrm{~Pb}^{* *}$ & TMT:Tree type & 1.8014 & 6 & 0.1099 \\
$\mathrm{Se}^{*}$ & - & - & - & - \\
& TMT & 0.4567 & 3 & 0.7133 \\
& Tree type & 0.9139 & 2 & 0.4053 \\
& TMT:Tree type & 0.1511 & 6 & 0.9883 \\
$\mathrm{Zn}^{2}$ & & & & \\
& TMT & 1.4870 & 3 & 0.2247 \\
& Tree type & 0.3382 & 2 & 0.7141 \\
& TMT:Tree type & 1.3200 & 6 & 0.2585 \\
\hline
\end{tabular}

${ }^{1}$ data $1 / 4$ root transformed to achieve residual normality

${ }^{2}$ data cube root transformed to achieve residual normality

* Not present in any leaf tissue

** Insufficient sample size for analysis 
JASMR, 2016 Volume 5 Issue 2

Table 2: Two-way Analysis of Variance results for floral metal concentrations by soil treatment and tree type at Tri-Valley Wildlife Management Area. Response variables were Treatment (TMT; control, plowed and disked, ripped, and ripped and plowed/disked) and Tree type (Pure American, $\mathrm{BC}_{1} \mathrm{~F}_{3}$, and $\mathrm{BC}_{2} \mathrm{~F}_{3}$ ).

\begin{tabular}{|c|c|c|c|c|}
\hline Metal & & $F$ & $\mathrm{df}$ & $P$ \\
\hline \multirow[t]{3}{*}{$\mathrm{Ag}^{1}$} & TMT & 2.5621 & 3 & 0.09655 \\
\hline & Tree type & 0.1253 & 2 & 0.88322 \\
\hline & TMT:Tree type & 0.3564 & 3 & 0.78530 \\
\hline \multirow[t]{3}{*}{$\mathrm{Al}^{1}$} & TMT & 0.2198 & 3 & 0.8810 \\
\hline & Tree type & 0.6789 & 2 & 0.5231 \\
\hline & TMT:Tree type & 1.0558 & 3 & 0.3990 \\
\hline As* & - & - & - & - \\
\hline $\mathrm{Cd}^{*}$ & - & - & - & - \\
\hline \multirow[t]{3}{*}{$\mathrm{Cu}^{1}$} & TMT & 2.5613 & 3 & 0.09663 \\
\hline & Tree type & 0.1194 & 2 & 0.88838 \\
\hline & TMT:Tree type & 0.2406 & 3 & 0.86654 \\
\hline \multirow[t]{3}{*}{ Mn55 } & TMT & 0.4827 & 3 & 0.6996 \\
\hline & Tree type & 0.5342 & 2 & 0.5976 \\
\hline & TMT:Tree type & 1.0014 & 3 & 0.4211 \\
\hline $\mathrm{Pb}^{*}$ & - & - & - & - \\
\hline \multirow[t]{3}{*}{$\mathrm{Se}$} & TMT & 0.6576 & 3 & 0.5915 \\
\hline & Tree type & 0.1201 & 2 & 0.8877 \\
\hline & TMT:Tree type & 1.5788 & 3 & 0.2389 \\
\hline \multirow[t]{3}{*}{$\mathrm{Zn}^{2}$} & TMT & 1.9858 & 3 & 0.1625 \\
\hline & Tree type & 1.1103 & 2 & 0.3568 \\
\hline & TMT:Tree type & 0.7847 & 3 & 0.5221 \\
\hline
\end{tabular}

${ }^{1}$ data square root transformed to achieve residual normality

${ }^{2}$ data cube root transformed to achieve residual normality

*Below level of detection in floral leaf tissue

\section{Comparison of Soil and Foliage Concentrations}

Differences in soil metal concentrations were detected when compared to Ohio state and Muskingum County averages (Table 3); elements in greater concentration in the soil included As, $\mathrm{Cu}, \mathrm{Mn}$, and Se (Fig. 1-3). Arsenic levels were higher in soils (10.63 ppm, 95\% CI [21.9, 30.1]) when compared to the background average for the state and county; 5.7 and 7.9, respectively. Arsenic was not detected in leaf tissue or floral tissue (Tables 3 and 4). 
Table 3. Mean concentrations of metals in soils (Mean ppm) with $95 \%$ confidence intervals (95\% CI) compared with average background metal concentration in Ohio soils (ppm) (Cox and Colvin, 1996), averages in Muskingum County (Logan and Miller, 1983; Schweitzer, 2016) and U.S. topsoil ranges (U.S. EPA, 1983).

\begin{tabular}{lccccc}
\hline Element & $\begin{array}{c}\text { Mean } \\
(\mathrm{ppm})\end{array}$ & $\begin{array}{c}95 \% \\
\mathrm{CI}\end{array}$ & $\begin{array}{c}\text { Ohio Soil } \\
\text { Ave }(\mathrm{ppm})\end{array}$ & $\begin{array}{c}\text { Muskingum } \\
\text { Ave }(\mathrm{ppm})\end{array}$ & $\begin{array}{c}\text { U.S. Topsoil } \\
\text { Range }(\mathrm{ppm})\end{array}$ \\
\hline $\mathrm{Ag}$ & 0.45 & {$[0.28,0.62]$} & 0.25 & $<1$ & $0.01-5$ \\
$\mathrm{Al}$ & $11,172.1$ & {$[9,864.9,12,479.3]$} & $7,685.0$ & $\mathrm{NA}$ & $10,000-300,000$ \\
$\mathrm{As}$ & 10.62 & {$[9.26,11.99]$} & 5.72 & 7.9 & $0.1-55$ \\
$\mathrm{Cd}$ & 0.21 & {$[0.16,0.25]$} & 0.507 & 0.2 & $0.1-1$ \\
$\mathrm{Cu}$ & 26.0 & {$[21.92,30.07]$} & 12 & 16 & $2-50$ \\
$\mathrm{Mn}$ & 767.84 & {$[658.46,877.23]$} & 459 & 459 & $600-6,000$ \\
$\mathrm{~Pb}$ & 14.37 & {$[13.15,15.60]$} & 16.2 & 28 & $22-44$ \\
$\mathrm{Se}$ & 3.55 & {$[2.56,4.55]$} & 0.25 & 0.3 & $0.1-3.9$ \\
$\mathrm{Zn}$ & 75.07 & {$[64.20,85.94]$} & 42.7 & 65 & $10-100$ \\
\hline
\end{tabular}

Table 4. Mean concentrations of metals in foliage and floral tissue of chestnuts (Pure American, $\mathrm{BC}_{1} \mathrm{~F}_{3}$, and $\mathrm{BC}_{2} \mathrm{~F}_{3}$ ) growing in the Tri-Valley research site as compared with ranges of metals in plant tissue (ppm) as reported in the literature (Kabata-Pendias and Pendias, 2001; Basar et al., 2009; Vamerali et al., 2010; Alloway, 2013; Gjengedal et al., 2015).

\begin{tabular}{lccccc}
\hline Element & $\begin{array}{c}\text { Chestnut } \\
\text { Foliage }(\mathrm{ppm})\end{array}$ & $\begin{array}{c}95 \% \\
\mathrm{CI}\end{array}$ & $\begin{array}{c}\text { Chestnut } \\
\text { Floral }(\mathrm{ppm})\end{array}$ & $\begin{array}{c}95 \% \\
\mathrm{CI}\end{array}$ & $\begin{array}{c}\text { Range in plant } \\
\text { tissues }\end{array}$ \\
\hline $\mathrm{Ag}$ & 0.18 & {$[0.05,0.31]$} & 0.10 & {$[0,0.20]$} & $0.05-1.5$ \\
$\mathrm{Al}$ & 78.43 & {$[53.75,103.12]$} & 44.05 & {$[20.55,67.55]$} & $30-250$ \\
$\mathrm{As}$ & $\mathrm{BDL}$ & - & $\mathrm{BDL}$ & - & $0.009-1.5$ \\
$\mathrm{Cd}$ & $\mathrm{BDL}$ & - & $\mathrm{BDL}$ & - & $0.1-2.4$ \\
$\mathrm{Cu}$ & 1.51 & {$[-1.0,4.02]$} & 21.70 & {$[12.58,30.82]$} & $4-15$ \\
$\mathrm{Mn} 55$ & $1,045.6$ & {$[834.3,1256.9]$} & 644.56 & {$[535.83,753.29]$} & $20-400$ \\
$\mathrm{~Pb}$ & 0.48 & {$[0-0.97]$} & 0.34 & {$[-0.19,0.85]$} & $0.1-10$ \\
$\mathrm{Se}$ & 1.85 & {$[0.51,3.19]$} & 7.32 & {$[5.78,8.85]$} & $<10$ \\
$\mathrm{Zn}$ & 48.41 & {$[10.83,86.0]$} & 55.03 & {$[15.67,94.40]$} & $27-100$ \\
\hline
\end{tabular}

Copper (26 ppm, 95\% CI [21.9, 30.1]), was higher in soils than county averages (16 ppm; Table 2), yet within common soil range (U.S. EPA, 1983). Copper was detected in foliage, however, in significantly smaller concentrations when compared to the soils $(\mathrm{t}=-10.88$, $\mathrm{df}=28$, $P<0.0001)$. When chestnut tissue was compared, $\mathrm{Cu}$ was in higher concentrations within the floral tissue than leaf tissue in plots that were ripped $(\mathrm{t}=-4.83, \mathrm{df}=22, P<0.0001$; Table 3; Fig. 1). 
JASMR, 2016 Volume 5 Issue 2

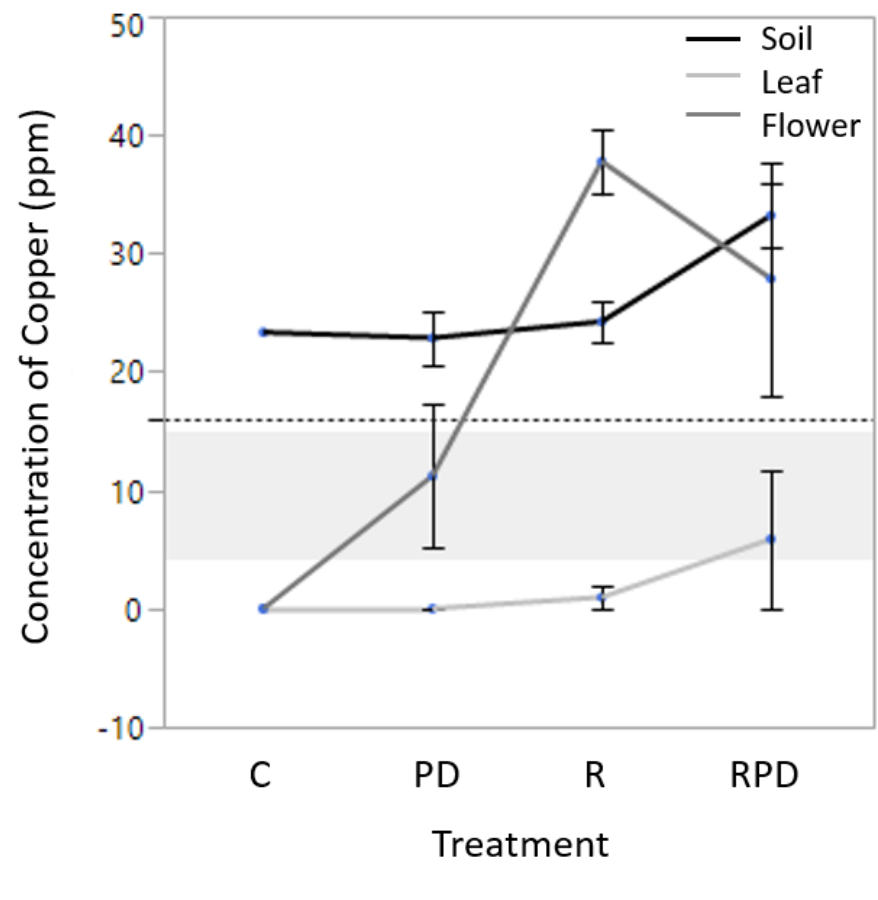

Figure 1. Mean $\mathrm{Cu}$ concentration $\pm 1 \mathrm{SE}$ (error bars) in soil (black lines), leaf tissue (light gray line), and floral tissue (dark gray line) on a reclaimed mine site in Dresden, Ohio, Muskingum County. County averages are represented by the dotted line and common range in plant tissue is illustrated with a gray band on the graph. Mean $\mathrm{Cu}$ soil concentrations were highest in floral tissue sampled from trees that were growing in the ripped plots.

Manganese soil concentrations were higher (767.9 ppm, 95\% CI [658.5, 877.2]) than the county average (459 ppm; Table 2). Manganese was unique with regard to the concentrations being higher in chestnut tree foliage when compared to the soils in plots that were RPD $(t=2.277$, df $=28, P=0.03$; Fig. 2). When comparing chestnut tissue, Mn had significantly higher concentrations in foliage than in floral tissue $(\mathrm{t}=3.27, \mathrm{df}=22, P=0.003$; Table 3$)$; this was higher when compared to common ranges in plant tissue (20-400; Table 3). 
JASMR, 2016 Volume 5 Issue 2

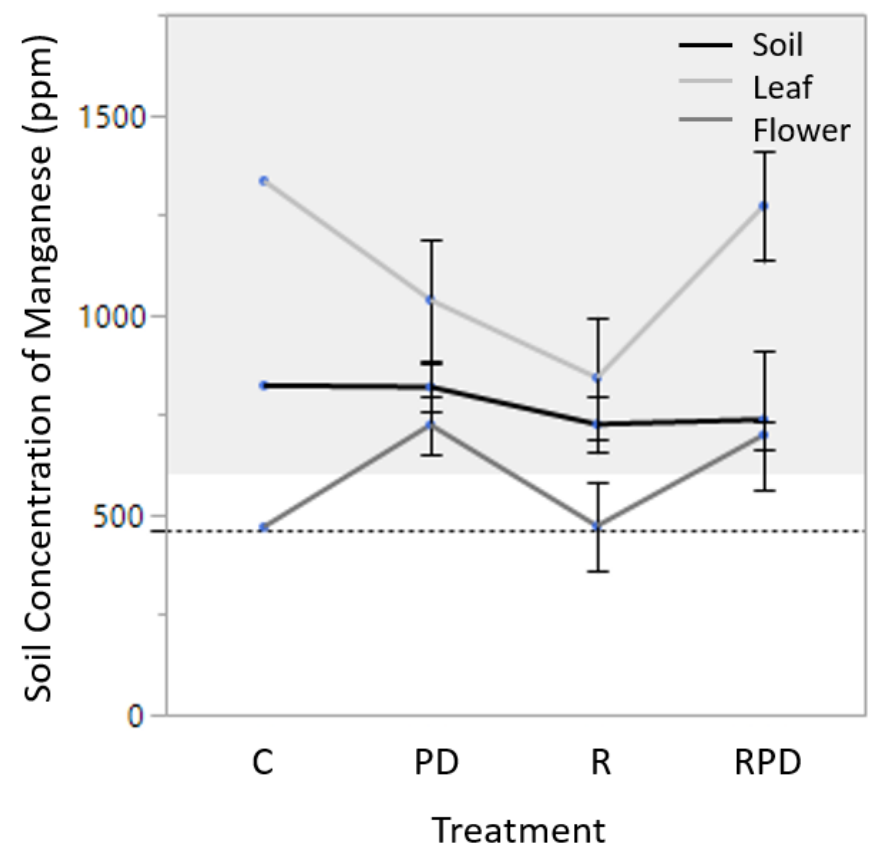

Figure 2. Mean Mn concentration \pm 1 SE (error bars) in soil (black lines), leaf tissue (light gray line), and floral tissue (dark gray line) on a reclaimed mine site in Dresden, Ohio, Muskingum County. County averages are represented by the dotted line and common range in plant tissue is illustrated with a gray band on the graph. Manganese levels were highest in foliage and lowest in floral tissue when compared to the soils.

Selenium was also higher in soils $(3.6 \mathrm{ppm}, 95 \% \mathrm{CI}[2.6,4.6])$ than state and county averages (0.3 ppm; Table 3). This was significantly greater than Se levels in leaf tissue in control and plowed and disked plots $(\mathrm{t}=-3.12, \mathrm{df}=28, P=0.004$; Fig. 3$)$. In addition, Se was in higher concentrations within the floral tissue than leaf tissues $(\mathrm{t}=-3.46, \mathrm{df}=22, P=0.002$; Table 4). However, each are considered within the United States (U.S.) topsoil range as reported by the U.S. EPA (1983). 
JASMR, 2016 Volume 5 Issue 2

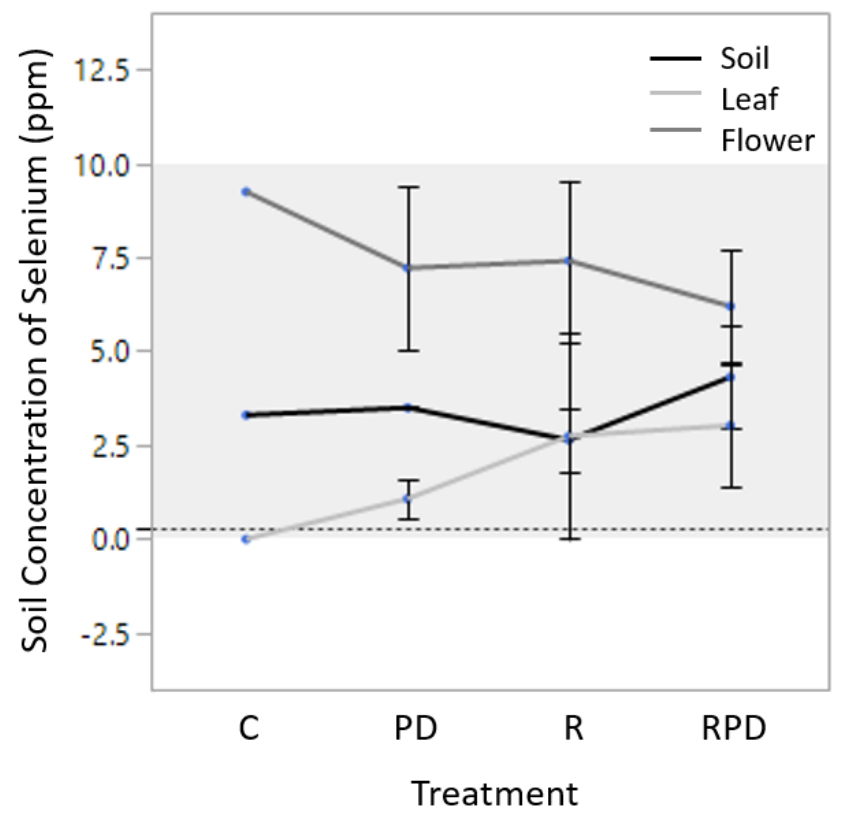

Figure 3. Mean Se concentration $\pm 1 \mathrm{SE}$ (error bars) in soil (black line), leaf tissue (light gray line), and floral tissue (dark gray line) on a reclaimed mine site in Dresden, Ohio, Muskingum County. County averages are represented by the dotted line and common range in plant tissue is illustrated with a gray band on the graph. Soil had higher Se levels than county average. In addition, Se was sampled in highest concentration in the flower tissue.

\section{$\underline{\text { Discussion }}$}

Long-term reclamation success includes monitoring for the bioaccumulation of heavy metal by-products associated with coal mining and reclamation. After eight years, soil preparation methods did not significantly modify soil metals or influence the hyper-accumulation of metals into chestnut tree tissue. However, it is noted that after eight years only one of the three control plots still harbored chestnut trees, illustrating increased mortality in the control plots through time. This could confound the results, if metal toxicity resulted in mortality on the control plots. However, no elevated levels were documented when soil was sampled from all control plots. In addition, the plow and disked plots did have replication and illustrated statistical similarities in soil and tissue levels with the control plots, which may suggest that soil compaction, rather than toxicity, was more likely the cause of tree mortality.

Some elements such as $\mathrm{As}, \mathrm{Cu}, \mathrm{Mn}$, and Se were found in higher concentrations in the soil than Ohio and county averages (Cox and Colvin, 1996; Logan and Miller, 1983; USGS 
Geochemistry and Minerology). However, the accumulation into the plant tissue was at levels that were not phototoxic (Wang, 1995). Some elements that were sampled in the soils (As and Cd), were not found within tissues, and therefore were not likely transferred into the food chain. Plants are known to have physical root barriers, mycorrhizal symbionts, and cellular mechanisms that aid in restricting metal entry into root cells and excluding elements from active metabolic locations (Bauman et al., 2012; Kalubi et al., 2016; Tosic et al., 2016). Another metal indicative of coal spoil is Se, which was detected in the highest accumulation within floral tissue. Selenium can biomagnify in ecosystems (Banuelos et al., 2002); it has been suggested that 4 ppm of Se in plants is the tolerance limit for animals and levels above 5 ppm could be potentially dangerous (Gough et al., 1979). Although we did not test levels in chestnut seed, we found floral tissue to average $7.3 \mathrm{ppm}$, which may merit closer inspection of the developing chestnut seed, which can be a major protein source for developing deciduous forests.

In our study, Mn was within reported soil ranges; however, concentrations were significantly higher in foliage (1045 ppm) with no observed phototoxic signs when compared to the soils. Other reclamation studies utilizing Castanea species have reported Henry chinkapin (C. henryi) growing in higher Mn (3000 mg/kg) and Cd (1-3.5 mg/kg) soil levels in a Chinese Mn mine with no toxic effect to vegetative tissue ( $\mathrm{Li}$ et al., 2007). Chinese chestnut (C. mollissima) has also been used as a restoration tree in China on tailings and minelands with high concentrations of metals (Shen et al., 2004). Despite that, Chinese chestnut had high survival and fast growth rates, which demonstrated its reliability as a restoration tree for loose minesoils and tailings (Shen et al., 2004). Castanea's tolerance of metals and fast growth rates merit their use in degraded sites to remedy and restore ecological function (Li et al., 2007). Although this can be a benefit when considering forest trees with bioremediation attributes, their edible parts had elevated $\mathrm{Cd}$ and $\mathrm{Pb}$ that exceeded food safety limits (Li et al., 2007).

Some metals are needed for plant growth in trace amounts but when present at high levels, can be toxic to plants (Lin and Aarts, 2012). In our study, these metal concentrations such as $\mathrm{Pb}, \mathrm{Cu}$, $\mathrm{Zn}$, in leaves were very close to the normal ranges for plants growing in uncontaminated soil (Kabata-Pendias and Pendias, 2001; Vamerali et al., 2010; Alloway, 2013). This is consistent with the notion that reclamation under SMCRA has led to some immediate improvements such as deterring heavy metals from entering the environment (Boyce, 1999). It is noted that $\mathrm{Cu}$ was higher in floral tissue in plots that were ripped and ripped/plowed/disked. Further, trends in our 
data may suggest that micronutrients such as $\mathrm{Cu}$ and $\mathrm{Zn}$ were in normal levels in plant tissues when grown in plots that were ripped or a combination of ripped and plowed/disked. The subtle decrease in $\mathrm{Zn}$ concentrations in plant tissue from the control and plow/disked plots may indicate a possible deficiency of these micronutrients, and this trend may become more apparent through time. Therefore, the provision of a deeper rooting medium via soil ripping may aid in the ability of a forest tree to compete for essential micronutrients among aggressive weedy species that are common on SMCRA sites. This could be due to greater mycorrhizal association that provides access to micronutrients in the soil profile, larger overall root volume allowing for deeper exploration, and/or greater access to water that provides greater nutrient transport.

In summary, no differences in metal concentrations were detected among soil treatments, but there were differences between soil and foliage, with some differences existing between tissue types. Fortunately, elements like $\mathrm{Cd}$ or As were not found in tree tissue, and therefore are not transferred to the food chain via chestnut herbivory or mast consumption. However, the elevated levels of $\mathrm{Se}$ and $\mathrm{Cu}$ in chestnut flower tissue merit further monitoring of chestnut seed to confirm that levels are safe for wildlife and human consumption. The long-term bioavailability of metals to plants and natural water ways are determined by the re-supply of the metal to the soil solution from current buried and stable sources (Roberts et al,. 2005). Changes in soil pH and organic matter contents, as well as interactions with other elements and substances in water, may drive the system for future plant availability (Fritioff and Greger, 2003; Tangahu et al., 2011; Kalubi et al., 2016).

\section{Acknowledgements}

This work was supported by National Technology and Transfer funds from the US Department of Interior (Office of Surface Mining Reclamation and Enforcement) and by The Research and Sponsored Program Grant from Western Washington University. Authors thank Julia Chapman and John Adamson for their research support.

\section{$\underline{\text { Literature Cited }}$}

Alloway, B.J. 2013. Heavy metals in soils, trace metals and metalloids in soils and their bioavailability. In Environmental Pollution, vol. 22, Eds. J.B. Alloway, and J.T. Trevors. New York: Springer. 
Bai, S., L Li, Y. Liu, R.K Dumroese, and R. Lv. 2009. Ostreopsis davidiana seedlings inoculated with ectomycorrhizal fungi facilitate formation of mycorrhizae on Pinus tabulaeformis seedlings. Mycorrhiza 19: 425-434. http://dx.doi.org/10.1007/s00572-009-0245-2

Banuelos, G.S., D.B. Vickerman, J.T. Trumble, M.C. Shannon, C.D. Davis, J.W. Finely, and H.F. Mayland. 2002. Biotranfer potential of selenium from plants used in phytoremediation. International Journal of Phytoremediation. 4:315-329.

http://dx.doi.org/10.1080/15226510208500090

Basar, H., S. Gurel, and A.V. Katkat. 2009. Metal status of soils and plants irrigated with water from lake Iznik, Turkey. Communications in Soil Science and Plant Analysis 40: 2545-2561. http://dx.doi.org/10.1080/00103620903111400

Bauman J.M., C.H. Keiffer, and S. Hiremath. 2012. Facilitation of American chestnut (Castanea dentata) seedling establishment by Pinus virginiana in mine restoration. International Journal of Ecology 2012: 1-12. http://dx.doi.org/10.1155/2012/257326

Bauman, J.M., C.H. Keiffer, and B.C. McCarthy. 2014. Backcrossed chestnut seedling performance and blight incidence (Cryphonectria parasitica) in restoration. New Forests 45: 813-828. http://dx.doi.org/10.1007/s11056-014-9439-3

Bauman, J.M., C. Cochran, J. Chapman, and K. Gilland. 2015. Plant community development following restoration treatments on a legacy reclaimed mine site. Ecological Engineering 83: 521-528. http://dx.doi.org/10.1016/i.ecoleng.2015.06.023

Boyce, S. 1999. Office of Surface Mining (OSM) revegetation team survey results. P. 31-35 In K. Vories and D. Throgmorton (Ed.) Proc. of the Enhancement of Reforestation at Surface Coal Mines: Technical Interactive Forum. 23-24 Mar. 1999. USDI, OSM, Coal Res. Ctr., Southern Illinois Univ. Carbondale.

Cavender, N., Byrd, S., Bechtoldt, C.L., and J.M. Bauman. 2014. Vegetation communities of recovering reclaimed grasslands following coal mining in southeastern Ohio. Northeastern Naturalist 21: 31-46. http://dx.doi.org/10.1656/045.021.0104

Chen, Y.Y., J. Wang, W. Gao, X.J. Sun, and S.Y. Xu. 2012. Comprehensive analysis of heavy metals in soils from Baoshan District, Shanghai: a heavily industrialized area in China. Environmental Earth Science 67: 2331-2343. http://dx.doi.org/10.1007/s12665-012-1680-5 
Clark S., H. McNab, D. Loftis, and S. Zarnoch. 2012. American chestnut growth and survival five years after planting in two silvicultural treatments in southern Appalachians, USA. Forests 3:1017-1033. http://dx.doi.org/10.3390/f3041017

Cox, C.A., and G.H. Colvin. 1996. Evaluation of background metal concentrations in Ohio Soils. Cox - Colvin \& Associates, Inc. Environmental Services, Columbus, Ohio.

Daniels, W.L. and D.F. Amos. 1985. Generating productive topsoil substitutes from hard rock overburden in the southern Appalachians. Environmental Geochemistry and Health 7: 8-15. http://dx.doi.org/10.1007/BF01875045

Fritioff A., and M. Greger. 2003. Aquatic and terrestrial plant species with potential to remove heavy metals from stormwater. International Journal of Phytoremediation 5: 211-224. http://dx.doi.org/10.1080/713779221

Fox, J. and S. Weisberg. 2011. An $\{\mathrm{R}\}$ Companion to Applied Regression, Second Edition. Thousand Oaks CA: Sage. 472 p.

Gjengedal, E., T. Martinsen, and E. Steinnes. 2015. Background levels of some major, trace, and rare earth elements in the indigenous plant species growing in Norway and the influence of soil acidification, soil parent material, and seasonal variants on these levels. Environmental Monitoring and Assessment, http://dx.doi.org/10.1007/s10661-015-4479-5

Gilland K.E. and B.C. McCarthy. 2012. Reintroduction of American chestnut (Castanea dentata) on reclaimed mine sites in Ohio: Microsite actors controlling establishment success. Northern Journal of Applied Forestry 29: 197-205. http://dx.doi.org/10.5849/njaf.11-041

Gough, L.P., H.T. Shacklette, and A.A. Case. 1979. Element concentration toxic to plants, animals, and man. U.S. Geological Survey Bulletin 1466. 80 pp.

Holl, K., 2002. Long-term vegetation recovery on reclaimed coal surface mines in the eastern USA. Journal of Applied Ecology 39: 960-970. http://dx.doi.org/10.1046/j.1365$\underline{2664.2002 .00767 . x}$

Jacobs, D.F., H.J. Dalgleish, and C.D. Nelson. 2013. A conceptual framework for restoration of threatened plants: the effective model of American chestnut (Castanea dentata) reintroduction. New Phytology 197: 378-393. http://dx.doi.org/10.1111/nph.12020 
JASMR, 2016 Volume 5 Issue 2

Kabata-Pendias, A. and H. Pendias. 2001. Trace elements in soils and plants. Boca Raton: CRC Press LLC.

Kalubi, K.N., M. Mehes-Smith, and A. Omri. 2016. Comparative analysis of metal translocation in red maple (Acer rubrum) and trembling aspen (Populus tremuloides) populations from stressed ecosystems contaminated with metals. Chemistry and Ecology 32: 312-323. http://dx.doi.org/10.1080/02757540.2016.1142978

Li, M.S., Y.P., Luo, and Z.Y. Su. 2007. Heavy metal concentration in soils and plant accumulation in a restored manganese mineland in Guangxi, South China. Environmental Pollution 147: 168-175. http://dx.doi.org/10.1016/j.envpol.2006.08.006

Lin, Y.F. and M.G.M. Aarts. 2012. The molecular mechanism of zinc and cadmium stress response in plants. Cellular and Molecular Life Sciences 19: 3187-3206. http://dx.doi.org/10.1007/s00018-012-1089-z

Logan, T.J. and R.H. Miller. 1983. Background levels of Heavy Metals in Ohio Farm Soils. The Ohio State University Ohio Agricultural Research and Development Center, Wooster, Ohio. Research Circular 275.

McCarthy, B.C., J.M. Bauman, and C.H. Keiffer. 2008. Mine reclamation strategies for the Restoration of American chestnut (Castanea dentata) Ecological Restoration 26: 292-294. http://dx.doi.org/10.3368/er.26.4.292

R Development Core Team, 2009. R: A language and environment for statistical computing. R Foundation for Statistical Computing, Vienna, Austria. ISBN 3-900051-07-0, URL Available online at http://www.R-project.org . Accessed July 18, 2014.

Richards, J.H. and M.M. Caldwell, 1987. Hydraulic lift: substantial nocturnal water transport between soil layers by Artemisia tridentata roots. Oecologia 73: 486-489. http://dx.doi.org/10.1007/BF00379405

Roberts, D., M. Nachtegaal, and D.L. Sparks. 2005. Speciation of Metals. pp. 619-653. In: Soil Science of America, 677 S. Segoe Road, Madison, WI 53711, USA. Chemical Processes in Soils. SSSA Book Series, no. 8.

Saylor, K.L., Land Cover Trends; Central Appalachians [U.S. Department of the Interior, U.S. Geological Survey (USGS), Washington D.C., 2008]; 
JASMR, 2016 Volume 5 Issue 2

http://landcovertrends.usgs.gov/east/eco69Report.html . Accessed July 18, 2014.

Shen, W.S., Cao, X.Z., and Y. Jin. 2004. Ecological Destruction and Reconstruction of Minelands. China Environmental Science Press, Beijing.

Skousen, J., C. Zipper, J. Burger, P. Angel, and C. Barton. 2011. Selecting topsoil substitutes for forestry mine soils. Proceedings American Society of Mining and Reclamation 2011 pp 591-609. http://dx.doi.org/10.21000/jasmr11010591

Skousen, J., T. Cook, L. Wilson-Kokes, and E. Pena-Yewtukhiw. 2013. Survival and Growth of chestnut backcross seed and seedlings on surface mines. Journal of Environmental Quality 42:690-695. http://dx.doi.org/10.2134/jeq2012.0368

Sokal, R.R. and F.J. Rohlf. 1995. Biometry, $3^{\text {rd }}$ Ed. W.H. Freeman and Company, New York

Schweitzer, P. 2016. USGS Geochemistry and Minerology. U.S. Department of the Interior. U.S. Geological Survey. http://mrdata.usgs.gov/ds-801/show-landscape.php?site_id=636 Accessed July 2016.

Tangahu B.V., S.R. Abdullah, H. Basri, M. Idris, N. Anuar, and M. Mukhlisi. 2011. A review on heavy metals $(\mathrm{AS}, \mathrm{Pb}$, and $\mathrm{Hg}$ ) uptake by plants through phytoremediation. International Journal of Chemical Engineering http://dx.doi.org/10.1155/2011/939161

Tosic, S., S. Alagic, M. Dimitrijevic, A. Pavlovic, and M. Nujkic. 2016. Plant parts of the apple tree (Malus spp.) as possible indicators of heavy metal pollution. Ambio 45, 501-512. http://dx.doi.org/10.1007/s13280-015-0742-9

U.S. EPA Office of Solid Waste and Emergency Response, Hazardous Waste Land Treatment, SW-874 (April 1983), page 273.

Vamerali, T., M. Bandiera, and G. Mosca. 2010. Field crops for phytoremediation of metalcontaminated land. Environmental Chemistry Letters 8: 1-17.

Wang, J.G. 1995. Soil Chemistry of plant nutrients. China Agricultural University Press, Beijing.

Wickham, J.D., K.H. Riitters, T.G. Wade, M. Coan, and C. Homer. 2007. The effect of Appalachian mountaintop mining on interior forest. Landscape Ecology 22:179-187. http://dx.doi.org/10.1007/s10980-006-9040-z

Wuertz, D. 2010. fBasics: Rmetrics - Markets and Basic Statistics. R package version 2110.79. 
JASMR, 2016 Volume 5 Issue 2

http://CRAN.R-project.org/package=fBasics

Zipper, C.E., J.A. Burger, J.G. Skousen, P.N. Angel, C.D. Barton, V. Davis, and J.A. Franklin. 2011. Restoring forests and associated ecosystem services on Appalachian coal surface mines.

Environmental Management 47:751-765. http://dx.doi.org/10.1007/s00267-011-9670-z 